\title{
The Role of Immunotherapy in the Treatment of Malignant Pleural Mesothelioma
}

\author{
Shantanu Banerji ${ }^{1, *(D)}$, Daniel E. Meyers ${ }^{2} \mathbb{D}$, Craig Harlos $^{3}$ and David E. Dawe $^{1}(\mathbb{D}$ \\ 1 CancerCare Manitoba Research Institute, Rady Faculty of Health Sciences, University of Manitoba, \\ Winnipeg, MB R3E 0V9, Canada; ddawe@cancercare.mb.ca \\ 2 Department of Medicine, University of Calgary, Calgary, AB T2N 2T9, Canada; daniel.meyers@ucalgary.ca \\ 3 CancerCare Manitoba, Rady Faculty of Health Sciences, University of Manitoba, \\ Winnipeg, MB R3E 0V9, Canada; charlos@cancercare.mb.ca \\ * Correspondence: sbanerji@cancercare.mb.ca
}

check for

updates

Citation: Banerji, S.; Meyers, D.E.; Harlos, C.; Dawe, D.E. The Role of Immunotherapy in the Treatment of Malignant Pleural Mesothelioma. Curr. Oncol. 2021, 28, 4542-4551. https://doi.org/10.3390/ curroncol28060385

Received: 15 October 2021 Accepted: 5 November 2021 Published: 8 November 2021

Publisher's Note: MDPI stays neutral with regard to jurisdictional claims in published maps and institutional affiliations.

Copyright: (c) 2021 by the authors. Licensee MDPI, Basel, Switzerland. This article is an open access article distributed under the terms and conditions of the Creative Commons Attribution (CC BY) license (https:/ / creativecommons.org/licenses/by/ $4.0 /)$.

\begin{abstract}
Malignant pleural mesothelioma is a rare and aggressive malignancy arising from mesothelial cells that line the serous membranes of the body. Cytotoxic chemotherapy has been a mainstay of therapy, resulting in a modest improvement in overall survival, but toxicity limits the eligible patient population. Few targeted agents beyond bevacizumab have demonstrated superior efficacy compared to placebos. With an improved understanding of the relationship between the immune system and cancer progression, immunotherapies are playing a greater role in the treatment of many cancers. Several early- and late-phase trials in malignant pleural mesothelioma, including assessments of the first-line efficacy of combination ipilimumab/nivolumab treatment, have now demonstrated promising results for both immune checkpoint inhibition and cell-based therapies. These immune therapies are likely to play a central role in the treatment of this disease going forward.
\end{abstract}

Keywords: immunotherapy; mesothelioma; nivolumab; ipilimumab; pembrolizumab; cell therapy

\section{Introduction}

Malignant pleural mesothelioma (MPM) is a rare but aggressive malignancy of which the incidence is highly correlated to the local importation and use of asbestos [1]. Incidence and mortality rates are increasing worldwide, with annual deaths estimated at 38,400 per year [2]. Optimal treatment can consider a multimodality approach, adding surgery and radiation to chemotherapy. However, a United States Surveillance, Epidemiology and End Results (SEER) database review of 14,228 cases diagnosed from 1973-2009 revealed that $59 \%$ of patients present with distant metastatic disease and only $23 \%$ of cases were treated with a cancer-directed surgery [3]. Median overall survival in this SEER populationbased study was 7 months. Independent predictors of better survival include female sex, local disease stage at diagnosis, and younger age, whereas weight loss and sarcomatoid histologic subtype are associated with worse prognosis [4]. As in many other common cancers, cytotoxic chemotherapy is the traditional standard of treatment for patients with local or advanced MPM. However, with the loss of immune control now recognized as a "hallmark" of carcinogenesis [5] and the development of tolerable agents, immune-directed therapies are playing a greater role in the treatment of mesothelioma. The recently reported improved efficacy of a first-line combination of ipilimumab/nivolumab over standard platinum/pemetrexed treatment represents a breakthrough for immune therapies in the treatment of MPM.

\section{Biology of Mesothelioma}

MPM arises from the malignant transformation of normal mesothelial cells that line the serous membranes of the body, including the pleura, peritoneum, pericardium, and tunica vaginalis [6]. Although normal mesothelial cells are of a mesodermal origin, they 
express both mesothelial and epithelial markers [7]. Decades of chronic injury to the mesothelial lining ultimately leads to malignant transformation through a variety of postulated mechanisms, including the generation of toxic oxygen radicals in response to chronic inflammation, as reviewed in [6,8]. The ultimate diagnosis of MPM requires histologic confirmation either via percutaneous needle or surgical biopsy. Although patients often present with effusions at diagnosis, cytology alone is considered inadequate for initial diagnosis but can be used to assess disease recurrence or metastases [1]. The three most common histologic variants in MPM are epithelioid mesothelioma ( $\sim 60 \%$ of new cases), sarcomatoid mesothelioma ( $20 \%)$, and biphasic mesothelioma, which requires $\geq 10 \%$ of both epithelioid and sarcomatoid cell components to be present $[1,6]$.

Genomic studies in MPM have revealed recurrent inactivating mutations, copy number loss, or gene fusions in several tumor suppressor genes, including ubiquitin carboxylterminal hydroxylase (BAP1), neurofibromin 2 (NF2), tumor protein 53 (TP53), large tumor suppressor kinase 2 (LATS2), SET domain-containing 2, histone lysine methyltransferase (SETD2), and cyclin-dependent kinase inhibitor 2A (CDKN2A) $[9,10]$. No recurrent activating mutations in oncogenes have been identified in MPM to date. However, downstream changes in key molecular pathways are being tested as rational strategies for novel targeted therapy in early-stage clinical trials, as reviewed previously [6]. In general, MPM has a lower protein-altering somatic mutation rate, especially compared to non-small-cell lung cancer (NSCLC) and small-cell lung cancer (SCLC). The mutation signatures most commonly seen in MPM indicate a base-agnostic mutagen (such as reactive oxygen species) and deamination of 5-methylcytosine to thymine in CpG islands [9]. Transversion mutations, commonly seen in association with exposure to cigarette smoke in lung cancer, are infrequent in mesothelioma.

MPM is associated with a diverse immune microenvironment consisting of tumorassociated macrophages (TAMS), cancer-associated fibroblasts, T-lymphocytes, and myeloidderived suppressor cells, which contribute to MPM pathogenesis through complex autocrine and paracrine signaling, as reviewed in [8]. Despite the prominence of immune cells, many cells such as TAMS demonstrate an immunosuppressive phenotype, whereas cytotoxic T-lymphocytes often display positive immune checkpoint markers such as PD-1, TIM3, and LAG3, which are suggestive of functional exhaustion [8]. Cancer-associated fibroblasts contribute to both the disruption of immune cell dysfunction as well as the promotion of angiogenesis through the production of vascular endothelial growth factor (VEGF), among others. Transcriptomic analyses of MPM have revealed that the immunecheckpoint protein programmed cell death ligand 1 (PD-L1) is significantly overexpressed in the sarcomatoid subtype [9], whereas V-domain Ig suppressor of T cell activation (VISTA) is significantly overexpressed in epithelioid [10] mesothelioma. Cancer cells and other immune cells within the tumor microenvironment can express the B7 family protein PD-L1 or its corresponding receptor to trigger an adaptive immune response and avoid host immune-mediated destruction [11]. PD-L1 expression in MPM tumor cells is associated with worse overall survival but does not entirely predict the response to PD-1/PD-L1 inhibitors [8,12]. VISTA is expressed on antigen-presenting cells and impedes $\mathrm{T}$ cell responses by reducing proliferation and cytokine production [13].

\section{Standard Systemic Therapy in Mesothelioma Prior to Immunotherapy}

Historically, single cytotoxic drugs such as cisplatin, gemcitabine, or doxorubicin were considered the standard agents for the treatment of advanced MPM. In 2003, the multitargeted antifolate agent pemetrexed was studied in combination with cisplatin. At a dose of cisplatin at $75 \mathrm{mg} / \mathrm{m}^{2}$ and pemetrexed at $500 \mathrm{mg} / \mathrm{m}^{2}$ every 3 weeks, Vogelzang and colleagues demonstrated a statistically significant improvement in survival with firstline combination chemotherapy over single-agent cisplatin [14] (Table 1). Median overall survival (mOS) improved from 9.3 months to 12.1 months (hazard ratio (HR) $0.77, p=0.02$ ) with the combination over cisplatin alone. Patients received six cycles of therapy on average, with $5.3 \%$ of patients receiving eight or more cycles. An overall response rate 
(ORR) of $41.3 \%$ was observed on the combination arm, setting a new standard for systemic therapy in mesothelioma. Significant Grade 3/4 toxicities in the cisplatin/pemetrexed arm included leukopenia (40\%), neutropenia (63\%), nausea (33\%) vomiting $(30 \%)$, and fatigue $(23 \%)$. The frequency of hematologic toxicity was reduced with the use of oral folic acid and intramuscular vitamin B12 supplementation. Similarly, the thymidylate synthesis inhibitor raltitrexed at $3 \mathrm{mg} / \mathrm{m}^{2}$ combined with cisplatin at $80 \mathrm{mg} / \mathrm{m}^{2}$ every 3 weeks improved mOS compared to cisplatin alone from 8.8 months to 11.4 months (HR $0.76, p=0.048$ ) [15]. With a median of five cycles, the ORR with combination therapy was $24 \%$ and Grade $3 / 4$ toxicities were twice as common compared to monotherapy.

Table 1. Key randomized trials in advanced malignant pleural mesothelioma.

\begin{tabular}{|c|c|c|c|c|c|c|c|c|c|c|c|}
\hline Reference & $\begin{array}{l}\text { Trial } \\
\text { Phase }\end{array}$ & $\begin{array}{l}\text { Line of } \\
\text { Therapy }\end{array}$ & $\begin{array}{l}\text { Histologic } \\
\text { Breakdown }\end{array}$ & $\begin{array}{l}\text { PDL1 } \\
\geq 1 \%\end{array}$ & $\begin{array}{c}\text { Control and } \\
\text { Experiment Arms }\end{array}$ & $\begin{array}{l}\text { Sample } \\
\text { Size }\end{array}$ & $\underset{\%}{\text { ORR, }}$ & $\underset{\%}{\text { DCR, }}$ & $\begin{array}{l}\text { mPFS, } \\
\text { Months }\end{array}$ & $\begin{array}{c}\text { mOS, } \\
\text { Months }\end{array}$ & $\begin{array}{c}\text { Hazard } \\
\text { Ratio }\end{array}$ \\
\hline \multicolumn{12}{|c|}{ Non-Immunotherapy Trials } \\
\hline $\begin{array}{l}\text { Vogelzang, } \\
2003[14]\end{array}$ & III & 1 st & $\begin{array}{c}68.3 \% \mathrm{E} \\
25.9 \% \mathrm{NE}\end{array}$ & NR & $\begin{array}{c}\text { Cisplatin } \\
\text { Cisplatin/Pemetrexed }\end{array}$ & $\begin{array}{l}222 \\
226\end{array}$ & $\begin{array}{l}16.7 \\
41.3\end{array}$ & $\begin{array}{l}\text { NR } \\
\text { NR }\end{array}$ & $\begin{array}{l}3.9 \\
5.7\end{array}$ & $\begin{array}{c}9.3 \\
12.1\end{array}$ & $\begin{array}{c}0.77 \\
p 0.02\end{array}$ \\
\hline $\begin{array}{c}\text { van Meerbeeck, } \\
2005 \text { [15] }\end{array}$ & III & 1 st & $\begin{array}{c}67.6 \% \mathrm{E} \\
24.4 \% \mathrm{NE}\end{array}$ & NR & $\begin{array}{c}\text { Cisplatin } \\
\text { Cisplatin/Raltitrexed }\end{array}$ & $\begin{array}{l}124 \\
126\end{array}$ & $\begin{array}{l}14 \\
24\end{array}$ & $\begin{array}{l}56.4 \\
66.7\end{array}$ & $\begin{array}{l}4.0 \\
5.3\end{array}$ & $\begin{array}{c}8.8 \\
11.4\end{array}$ & $\begin{array}{c}0.76 \\
p 0.048\end{array}$ \\
\hline Zalcman, 2016 [16] & III & 1 st & $\begin{array}{c}81 \% \mathrm{E} \\
19 \% \mathrm{NE}\end{array}$ & NR & $\begin{array}{c}\text { Cisplatin/Pemetrexed } \\
\text { Cisplatin/Pemetrexed/ } \\
\text { Bevacizumab }\end{array}$ & $\begin{array}{l}225 \\
223\end{array}$ & $\begin{array}{l}\text { NR } \\
\text { NR }\end{array}$ & $\begin{array}{l}\text { NR } \\
\text { NR }\end{array}$ & $\begin{array}{l}7.3 \\
9.2\end{array}$ & $\begin{array}{l}16.1 \\
18.8\end{array}$ & $\begin{array}{c}0.77 \\
p 0.017\end{array}$ \\
\hline Scagliotti, 2019 [17] & III & 1 st & $\begin{array}{l}96 \% \mathrm{E} \\
4 \% \mathrm{NE}\end{array}$ & NR & $\begin{array}{l}\text { Cisplatin/Pemetrexed } \\
\text { Cisplatin/Pemetrexed/ } \\
\text { Nintedanib }\end{array}$ & $\begin{array}{l}229 \\
229\end{array}$ & $\begin{array}{l}43 \\
45\end{array}$ & $\begin{array}{l}93 \\
91\end{array}$ & $\begin{array}{l}7.0 \\
6.8\end{array}$ & $\begin{array}{l}16.1 \\
14.4\end{array}$ & $\begin{array}{c}1.12 \\
p 0.54\end{array}$ \\
\hline \multicolumn{12}{|c|}{ Immunotherapy Trials } \\
\hline Baas, 2021 [18] & III & 1 st & $\begin{array}{c}75 \% \mathrm{E} \\
25 \% \mathrm{NE}\end{array}$ & $77 \%$ & $\begin{array}{l}\text { Platinum/Pemetrexed } \\
\text { Nivolumab/Ipilimumab }\end{array}$ & $\begin{array}{l}302 \\
303\end{array}$ & $\begin{array}{l}43 \\
40\end{array}$ & $\begin{array}{l}85 \\
77\end{array}$ & $\begin{array}{l}7.2 \\
6.8\end{array}$ & $\begin{array}{l}14.1 \\
18.1\end{array}$ & $\begin{array}{c}0.74 \\
p 0.002\end{array}$ \\
\hline Maio, 2017 [19] & $\mathrm{Illb}$ & $\begin{array}{l}\text { 2nd }(63 \%) \\
\text { 3rd }(37 \%)\end{array}$ & $\begin{array}{c}83 \% \mathrm{E} \\
16 \% \mathrm{NE}\end{array}$ & NR & $\begin{array}{c}\text { Placebo } \\
\text { Tremelimumab }\end{array}$ & $\begin{array}{l}189 \\
382 \\
\end{array}$ & $\begin{array}{l}1.1 \\
4.5\end{array}$ & $\begin{array}{l}21.7 \\
27.7\end{array}$ & $\begin{array}{l}2.7 \\
2.8\end{array}$ & $\begin{array}{l}7.3 \\
7.7\end{array}$ & $\begin{array}{c}0.92 \\
p 0.41\end{array}$ \\
\hline Popat, 2020 [20] & III & 2nd & $\begin{array}{c}89 \% \mathrm{E} \\
11 \% \mathrm{NE}\end{array}$ & $46 \%$ & $\begin{array}{l}\text { Gemcitabine or } \\
\text { Vinorelbine } \\
\text { Pembrolizumab }\end{array}$ & $\begin{array}{l}71 \\
73\end{array}$ & $\begin{array}{c}6 \\
22\end{array}$ & $\begin{array}{c}38 \\
45.2\end{array}$ & $\begin{array}{l}3.4 \\
2.5\end{array}$ & $\begin{array}{l}11.7 \\
10.7\end{array}$ & $\begin{array}{c}1.04 \\
p 0.85\end{array}$ \\
\hline Fennell, 2021 [21] & III & $\begin{array}{l}\text { 2nd (30\%) } \\
\text { 3rd (57\%) }\end{array}$ & $\begin{array}{c}88 \% \mathrm{E} \\
12 \% \mathrm{NE}\end{array}$ & $24 \%$ & $\begin{array}{c}\text { Placebo } \\
\text { Nivolumab }\end{array}$ & $\begin{array}{l}111 \\
221\end{array}$ & $\begin{array}{l}\text { NR } \\
10.4\end{array}$ & $\begin{array}{l}\text { NR } \\
\text { NR }\end{array}$ & $\begin{array}{l}1.8 \\
3.0\end{array}$ & $\begin{array}{l}6.6 \\
9.2\end{array}$ & $\begin{array}{c}0.72 \\
p 0.018\end{array}$ \\
\hline
\end{tabular}

Abbreviations: PDL1, programmed death ligand 1; ORR, overall response rate; DCR, disease control rate; mPFS, median progression free survival; mOS, median overall survival; E, epithelioid; NE, non-epithelioid; NR, not reported; platinum, carboplatin, or cisplatin.

The outcomes for newly diagnosed advanced mesothelioma were further improved with the addition of the VEGF inhibitor bevacizumab to cisplatin/pemetrexed in the Phase III Mesothelioma Avastin Cisplatin Pemetrexed Study (MAPS). Bevacizumab at $15 \mathrm{mg} / \mathrm{m}^{2}$, when added to standard cisplatin/pemetrexed treatment, improved mOS from 16.1 months to 18.8 months (HR 0.77; $p=0.017$ ) compared to placebo [16]. Seventy-five percent of patients in the experimental arm completed all six cycles of cisplatin/pemetrexed and a treatment benefit was observed regardless of age, sex, and histologic subtype. Although toxicity was reported to be manageable, the addition of bevacizumab led to an increase in the frequency of an any-grade creatinine concentration rise (10.6\%), hemorrhage (33.8\%), cardiovascular adverse events (59\%), hypertension (55\%), and arterial/venous thromboembolic events (5.9\%) compared to placebo. Allowing for the limitations of a short-term follow-up, adding bevacizumab did not negatively impact patient quality of life. Although cisplatin/pemetrexed/bevacizumab promised to be a new standard of care in MPM, the combination has not been adopted universally across the globe [1]. With the success of the VEGF monoclonal antibody bevacizumab in combination therapy, the oral anti-angiogenic agent nintedanib was tested in combination with up to six cycles of cisplatin/pemetrexed in a Phase III trial. Nintedanib targets VEGF receptors 1-3, PDGF receptors alpha and beta, FGF receptors 1-3, and Src and Abl kinases. With a median duration of therapy of 5.3 months, nintedanib failed to meet its primary endpoint of improved median progression free survival (mPFS) compared to placebo (HR 1.01; $p$ 0.91) [17]. 
The role of angiogenesis pathway inhibition in MPM remains unclear. Therefore, the standard of care for the first-line treatment of MPM has remained cisplatin/pemetrexed; however, bevacizumab can be considered in combination where accessible.

\section{The Emerging Role of Immunotherapy in MPM}

The last decade has presented a paradigm shift in the way we understand the relationship between the immune system, cancer development, and subsequent disease progression. Monoclonal antibodies directed against cytotoxic T lymphocyte antigen 4 (CTLA4) or programmed cell death 1 (PD-1) or its cognate ligand PD-L1 have received regulatory approval across the globe, alone or in combination with chemotherapy, for the treatment of a variety of malignancies, including other thoracic cancers such as NSCLC and SCLC [22-25].

\subsection{Early-Phase Trials}

The CTLA4 inhibitor tremelimumab was the first immune checkpoint inhibitor assessed in mesothelioma. Calabro and colleagues enrolled 29 patients with platinumresistant disease on a Phase II trial of tremelimumab $15 \mathrm{mg} / \mathrm{kg}$ every 90 days until progressive disease or toxicity [26]. The median age was 64 with $86 \%$ of participants having epithelioid histology. Only two patients (6.9\%) had an ORR and mOS was 10.7 months, with $36.7 \%$ surviving for 2 years. Grade 3/4 toxicity included colitis/diarrhea (13\%), an increase in hepatic transaminase rise $(6 \%)$, an increase in amylase $(3 \%)$, and peripheral neuropathy (3\%). A more intense schedule of intravenous tremelimumab $(10 \mathrm{mg} / \mathrm{kg}$ every 4 weeks for seven doses, then every 12 weeks thereafter until treatment discontinuation) was compared to placebo in the randomized Phase IIb DETERMINE study [19] (Table 1). Patients with unresectable MPM who failed a platinum/pemetrexed regimen were randomized 2:1 to tremelimumab versus placebo. The median age was $66,83 \%$ had epithelioid histology, and 69\% had Stage IV disease. The median treatment duration with the CTLA4 inhibitor was 57 days and mOS was similar between groups at 7.7 and 7.3 months (HR $0.92, p 0.41)$ in the tremelimumab and placebo groups, respectively. An ORR was seen in only $4.5 \%$ of cases and the sarcomatoid subtype (accounting for $6 \%$ of cases) numerically seemed to benefit from the CTLA4 inhibitor more than the epithelioid subtype cases. No new adverse safety signal was observed.

The first study to assess the efficacy of the PD-1 inhibitor pembrolizumab was published in 2017 [27]. In the Phase 1b KEYNOTE-028 trial, Alley and colleagues enrolled patients with PD-L1 $\geq 1 \%$-positive MPM-defined by membranous PD-L1 expression in $1 \%$ or more of the tumor and associated inflammatory cells, or positive staining in the stroma. Patients received pembrolizumab at $10 \mathrm{mg} / \mathrm{kg}$ intravenously every 2 weeks until disease progression, intolerable toxicity, or study withdrawal. Of 83 patients screened for enrollment via the testing of PD-L1 expression, $38(46 \%)$ were positive and 25 were eligible for inclusion. Of these 25 patients, 92\% were previously treated with cytotoxic chemotherapy and $72 \%$ had epithelioid histology. An ORR of $20 \%$ was observed (all partial responses) with a median duration of response of 12 months. Median overall survival was 18 months, with two patients completing the protocol-specified maximum 24 months of treatment. Treatment-related Grade 3 toxicity, observed in one patient each, included thrombocytopenia; dyspnea; iridocyclitis; alanine aminotransferase increase; and a combination of neutropenia, decreased appetite, and pyrexia (in the same patient). Multiple other Phase I/II non-randomized single agent PD-1/PD-L1 inhibitors studies including pembrolizumab, nivolumab, and avelumab have demonstrated an ORR of $19 \%-38 \%$ and an mOS of 7.2-17.3 months, as previously reviewed [28].

The modest but encouraging results with single-agent CTLA4 and PD-1/PD-L1 agents prompted combination trials to assess potential synergistic effects. The open-label Phase II NIBIT-MESO-1 study assessed treatment with tremelimumab at $1 \mathrm{mg} / \mathrm{kg}$ with durvalumab at $20 \mathrm{mg} / \mathrm{kg}$ every 4 weeks for four doses, followed by durvalumab alone for nine doses [29]. The tumor response was assessed using the modified Response Evaluation Criteria in Solid Tumors (mRECIST) for pleural mesothelioma, which measure 
tumor thickness perpendicular to the chest wall or mediastinum to determine the response. A total of 40 patients were assessed: with a median age of $64,80 \%$ epithelioid histology, $73 \%$ Stage IV disease, and $30 \%$ as a first-line therapy. The ORR, as determined by mRECIST, was $25 \%$ and mOS was 16.6 months. Responses did not correlate with PD-L1 expression status and 18\% of patients experienced Grade 3/4 immune-related toxicity, reversible with protocol guidelines. The French randomized open-label Phase II MAPS2 trial directly compared single-agent nivolumab at $3 \mathrm{mg} / \mathrm{kg}$ every 2 weeks to nivolumab plus ipilimumab at $3 \mathrm{mg} / \mathrm{kg}$ every 6 weeks until progression or toxicity in previously treated patients with advanced MPM [30]. A total of 125 patients were randomized to the two treatment arms: with a median age of 71, 84\% epithelioid histology, and 69\% in the second-line setting. The primary endpoint of disease control at 12 weeks was met in $44 \%$ of patients receiving nivolumab and $50 \%$ receiving the combination, which exceeded the prespecified target of $40 \%$. Although an ORR was seen in $19 \%$ of nivolumab and $28 \%$ nivolumab/ipilimumab patients, disease hyper-progression (defined as $>80 \%$ growth at 12 weeks) was seen in $10 \%$ and $4 \%$ of patients, respectively. mOS was 11.9 months with nivolumab and 15.9 months with the combination. Grade 3/4 adverse events were seen in $14 \%$ of patients on monotherapy compared to $28 \%$ in the combination arm. Studies of comprehensive immune cell profiling suggest that the PD-1/CTLA4 combination increases the activation and proliferation of effector memory T-cells compared to monotherapy [31].

\subsection{Phase III Registration Trials of Immunotherapy in MPM}

In the past year, three randomized Phase III studies have explored the role of PD-1 inhibitors alone or in combination with a CTLA4 inhibitor in advanced MPM $[18,20,21]$. The PROMISE-meso trial examined the role of pembrolizumab at a 200-mg fixed dose every 3 weeks compared to single-agent intravenous (IV) gemcitabine at $1000 \mathrm{mg} / \mathrm{m}^{2}$ (days 1 and 8) every 3 weeks or vinorelbine at $30 \mathrm{mg} / \mathrm{m}^{2} \mathrm{IV}$ (days 1 and 8 ) or $60 / 80 \mathrm{mg} / \mathrm{m}^{2}$ oral (days 1 and 8) until progression. Cross-over to pembrolizumab was permitted in the chemotherapy arm [20]. A total of 144 patients who had progressed after previous platinum-based chemotherapy, stratified by histologic subtype, were randomized 1:1; $63 \%$ of patients randomized to single-agent chemotherapy subsequently crossed over to pembrolizumab. The median age was 70 , with almost $90 \%$ having epithelioid histology. Although ORR with pembrolizumab was $22 \%$ compared to $6 \%$ with chemotherapy, this did not translate into any significant differences in mPFS or mOS even when correcting for cross-over or stratifying by PD-L1 expression status. Rates of treatment-related adverse events were similar between both arms. In early 2021, the results of the Phase III CONFIRM trial were presented at the 2020 World Conference on Lung Cancer [21]. After stratifying for epithelioid versus non-epithelioid histology, 332 MPM patients who progressed on one or more previous lines of chemotherapy were randomized 2:1 to nivolumab at a fixed dose of $240 \mathrm{mg}$ IV every 14 days or placebo IV solution. Co-primary endpoints were overall survival and investigator-reported mPFS. The median age was 70 , with $88 \%$ with epithelioid histology, and 57\% treated in the 3rd line setting. Median OS was significantly improved at 9.2 months on nivolumab versus 6.6 months on placebo (HR 0.72, $p$ 0.018) and was independent of PD-L1 expression status, but subgroup analysis suggested that patients with epithelioid histology derived a greater survival benefit. Rates of any-grade or $\geq$ Grade 3 side effects were similar between nivolumab and placebo. Based on these results, single-agent nivolumab can be considered an option for MPM patients who have failed previous chemotherapy.

Finally, the CheckMate 743 randomized, open-label, Phase III study directly compared the global standard platinum/pemetrexed to nivolumab plus ipilimumab as a first-line therapy for advanced MPM [18]. The control arm received standard cisplatin/pemetrexed dosing for up to six cycles. Carboplatin (area under the curve: $5 \mathrm{mg} / \mathrm{mL} / \mathrm{min}$ ) could be substituted for cisplatin. The experimental arm received nivolumab plus ipilimumab at similar doses to the MAPS2 trial and treatment was permitted for up to 2 years. The primary endpoint was overall survival. A total of 605 patient were randomized 1:1, stratified 
by sex and histology to chemotherapy or immunotherapy, with a median age of $69,75 \%$ epithelioid histology, 12\% sarcomatoid histology, and 50\% Stage IV disease. PD-L1 status was quantifiable in $97 \%$ of patients and $77 \%$ of cases showed staining in $\geq 1 \%$ of tumor cells. Sixty-two percent of chemotherapy patients completed all six cycles of therapy and the median duration of nivolumab/ipilimumab therapy was 5.6 months. The study met its primary endpoint with a statistically significant improvement in mOS at 14.1 months in the control arm and 18.1 in the immunotherapy arm (HR $0.74, p=0.002)$. Upon disease progression, $44 \%$ of patients in the immunotherapy arm received subsequent systemic therapy, $43 \%$ of whom received chemotherapy. In the chemotherapy arm $41 \%$ received subsequent therapy: $20 \%$ received immunotherapy and $31 \%$ received alternate chemotherapy.

Although mOS with nivolumab/ipilimumab was similar in epithelioid and nonepithelioid patients, the latter group derived significantly less benefit with chemotherapy with mOS of 16.5 versus 8.8 months, respectively. Objective response rates with immunotherapy were $40 \%$, similar to that of chemotherapy both in the MAPS2 trial and historical clinical trials of platinum/pemetrexed. PD-L1 positivity did not correlate with the degree of benefit. As with many studies in which immunotherapy is compared to chemotherapy, mPFS initially appears worse in part due to hyper-progression on nivolumab/ipilimumab, but numerically better at landmark time points (e.g., 12 months at $30 \%$ and $24 \%$, respectively). Grade $3 / 4$ adverse events were seen in $30 \%$ of the immunotherapy group and $32 \%$ receiving chemotherapy, although the rates of treatment-related Grade $3 / 4$ serious events were greater in the nivolumab/ipilimumab arm ( $15 \%$ versus $6 \%)$. On the strength of these results, the United States Food and Drug Administration approved nivolumab in combination with ipilimumab for the first-line treatment of adults with unresectable malignant pleural mesothelioma in October 2020 and the European Medicines Agency adopted a favorable opinion in 2021 [32,33].

\subsection{First-Line Immunotherapy in Combination with Chemotherapy}

The results of treatment with immune checkpoint inhibitors are challenging existing chemotherapy standards of care and pose an efficacious first-line option, without an excess of adverse safety signals, especially for chemo-resistant sarcomatoid histologic subtypes. However, with response rates still around $40 \%$ overall, there is the possibility that immunotherapy in combination with chemotherapy may improve patient outcomes even further and avoid hyper-progression on immune checkpoint inhibitors, as seen in NSCLC and SCLC $[23,24]$. The PrE0505 Phase II single-arm study combined six cycles of platinum/pemetrexed with durvalumab followed by maintenance durvalumab for up to 1 year [34]. Median OS for the 55 treated patients was 20.4 months with an ORR of $56 \%$. Grade 3 or higher adverse events occurred in $65 \%$ of patients with most related to chemotherapy. Durvalumab, pembrolizumab, or atezolizumab in combination with chemotherapy \pm bevacizumab are currently being compared to standard-of-care chemotherapy in Phase III randomized control trials, with results expected as early as 2022 (Table 2).

Table 2. Ongoing Phase III chemotherapy combined with immune checkpoint inhibitor trials in advanced malignant pleural mesothelioma.

\begin{tabular}{|c|c|c|c|c|c|c|c|}
\hline $\begin{array}{l}\text { ClinicalTrials.gov } \\
\text { Identifier }\end{array}$ & Acronym & Trial Phase & $\begin{array}{l}\text { Estimated } \\
\text { Enrollment }\end{array}$ & Control Arm & Experimental Arm & $\begin{array}{l}\text { Primary } \\
\text { Endpoint }\end{array}$ & $\begin{array}{c}\text { Estimated Primary } \\
\text { Completion Date }\end{array}$ \\
\hline NCT02784171 & CCTG-IND227 & III & 520 & $\begin{aligned} & \text { Cisplatin } \\
+ & \text { Pemetrexed }\end{aligned}$ & $\begin{array}{c}\text { Cisplatin } \\
+ \text { Pemetrexed } \\
+ \text { Pembrolizumab }\end{array}$ & Overall survival & July 2022 \\
\hline NCT03762018 & BEAT-meso & III & 400 & $\begin{array}{l}\text { Carboplatin } \\
\text { + Pemetrexed } \\
+ \text { Bevacizumab }\end{array}$ & $\begin{array}{c}\text { Carboplatin } \\
\text { + Pemetrexed } \\
+ \text { Bevacizumab } \\
+ \text { Atezolizumab }\end{array}$ & Overall survival & January 2024 \\
\hline NCT04334759 & DREAM3R & III & 480 & $\begin{array}{l}\text { Cisplatin/Carboplatin } \\
\quad+\text { Pemetrexed }\end{array}$ & $\begin{array}{l}\text { Cisplatin/Carboplatin } \\
\text { + Pemetrexed } \\
\text { + Durvalumab }\end{array}$ & Overall survival & April 2025 \\
\hline
\end{tabular}




\subsection{Immunotherapy Strategies beyond Current Immune Checkpoint Inhibitors}

Current therapeutic advancements with PD-1/PD-L1/CTLA4 inhibitors are encouraging but do not appear to be effective in all patients with MPM. A common theme in the existing immune checkpoint inhibitor approach is the requirement of an already primed immune microenvironment, specifically with the presentation of tumor antigens by antigen-presenting cells (APC) and activated T-cell mediated cytotoxicity [35]. The failure of adequate APC function or exhaustion of T-cell cytotoxic activity can therefore ultimately impact this response. Alternate immune checkpoints such as TIM-3 or LAG-3 are overexpressed in mesothelioma-associated T-lymphocytes and the combination blockade of these markers along with PD-L1 is showing promise in preclinical models [36]. Similarly, selectively targeting immunotoxins to mesothelin, a cell surface protein that is commonly expressed in mesothelioma, appears to enhance the effect of PD-1 inhibition [37].

Cellular therapy has been proposed as another novel approach to overcome the immunosuppressive microenvironment in MPM. Dendritic cell therapy (DCT) aims to expand the population of tumor-specific APC to generate a T-cell response. In brief, both a tumor cell lysate and peripheral blood mononuclear cells are obtained from a patient. The latter is enriched ex vivo to generate mature dendritic cells (DCs). Both autologous tumor lysate and DCs are then reinjected into the patient in order to trigger a tumor antigenspecific T-cell response [38]. A combined analysis of three studies with 29 MPM patients treated with DCT between 2006 and 2015 demonstrated an mOS of 27 months and a 5-year overall survival of 20.7\% [39]. This approach is being tested against best supportive care in 230 participants through the Phase III DENdritic Cell Immunotherapy for Mesothelioma (DENIM) trial and the results are expected to be report in 2023 (NCT03610360).

Chimeric antigen receptor (CAR)-T cell therapy aims to address the issue of T-cell exhaustion. In brief, T-cells are extracted from patient peripheral blood and then genetically engineered to express a tumor-associated antigen-specific chimeric antigen receptor on their cell surface and expanded ex vivo. Engineered CAR-T cells undergo autologous re-injection into the patient and can identify specific tumor antigens without the requirement of an APC. Mesothelin-targeted CAR-T therapy in combination with pembrolizumab has demonstrated disease control [40]. Several early-stage trials are underway, as reviewed elsewhere [41], but likely require several more years of optimization before more widespread use.

Finally, oncolytic viral therapy can also be used to generate a disease-specific immune response when injected directly into the tumor, especially when modified to express immunogenic protein-like interferon- $\alpha$ or $-\beta$ [42]. Early studies have demonstrated potential evidence of disease benefits and this strategy is currently being tested in the Phase III INFINITE clinical trial of recombinant adenoviral interferon combined with celecoxib and gemcitabine in MPM (NCT03710876).

\section{Conclusions}

Over the past 20 years, new agents have expanded the treatment compendium and expected survival for patients with advanced malignant pleural mesothelioma. Immune checkpoint inhibitors now pose a viable alternative to cytotoxic chemotherapy in many patients, either in treatment-naïve patients or as a subsequent line of therapy. Advances in cellular therapies also provide further opportunities to harness the immune system in the treatment of this disease. The optimal timing and combinations of these therapies are still being defined to maximize benefits but present an exciting future in the treatment of this challenging disease. 
Author Contributions: Conceptualization, S.B. and D.E.D.; writing-original draft preparation, S.B., D.E.M.; writing-review and editing, S.B., D.E.M., C.H. and D.E.D. All authors have read and agreed to the published version of the manuscript.

Funding: S.B. and D.E.D. have received research funding from the CancerCare Manitoba Foundation. This article, as well as several others in this Special Issue, was supported by grants from Amgen Canada, AstraZeneca Canada Inc, Eisai Canada Limited, Hoffman La Roche Canada (journal publication fees only), Jazz Pharmaceuticals Canada Inc., Novartis Canada, Sanofi Canada, Pfizer Canada Inc. Funds were used to pay journal publication fees, provide administrative support and honorariums for some authors. These entities did not influence the content of the articles, nor did they review the article prior to publication.

Conflicts of Interest: S.B. is actively participating in immunotherapy clinical trials sponsored by AstraZeneca and Roche. S.B. has also received honoraria for advisory board participation or educational content from AstraZeneca, Bayer, Bristol-Myers-Squibb, Lilly, Merck, Novartis, Pfizer, Roche, and Takeda. S.B. has also received a research grant from Roche. Daniel Meyers: nothing to disclose. Craig Harlos is actively participating in immunotherapy clinical trials sponsored by AstraZeneca and Roche. D.E.D. is actively participating in immunotherapy clinical trials sponsored by AstraZeneca and Roche. D.E.D. has also received honoraria for advisory board participation or educational content from AstraZeneca, Bristol-Myers-Squibb, Merck, Novartis, Boehringer-Ingelheim. D.E.D. has also received a research grant from AstraZeneca.

\section{References}

1. Scherpereel, A.; Opitz, I.; Berghmans, T.; Psallidas, I.; Glatzer, M.; Rigau, D.; Astoul, P.; Bolukbas, S.; Boyd, J.; Coolen, J.; et al. ERS/ESTS/EACTS/ESTRO guidelines for the management of malignant pleural mesothelioma. Eur. Respir. J. 2020, 55, 1900953. [CrossRef]

2. Odgerel, C.O.; Takahashi, K.; Sorahan, T.; Driscoll, T.; Fitzmaurice, C.; Yoko, O.M.; Sawanyawisuth, K.; Furuya, S.; Tanaka, F.; Horie, S.; et al. Estimation of the global burden of mesothelioma deaths from incomplete national mortality data. Occup. Environ. Med. 2017, 74, 851-858. [CrossRef]

3. Taioli, E.; Wolf, A.S.; Camacho-Rivera, M.; Kaufman, A.; Lee, D.S.; Nicastri, D.; Rosenzweig, K.; Flores, R.M. Determinants of Survival in Malignant Pleural Mesothelioma: A Surveillance, Epidemiology, and End Results (SEER) Study of 14,228 Patients. PLoS ONE 2015, 10, e0145039. [CrossRef] [PubMed]

4. Brims, F.J.; Meniawy, T.M.; Duffus, I.; de Fonseka, D.; Segal, A.; Creaney, J.; Maskell, N.; Lake, R.A.; de Klerk, N.; Nowak, A.K. A Novel Clinical Prediction Model for Prognosis in Malignant Pleural Mesothelioma Using Decision Tree Analysis. J. Thorac. Oncol. 2016, 11, 573-582. [CrossRef]

5. Hanahan, D.; Weinberg, R.A. Hallmarks of Cancer: The Next Generation. Cell 2011, 144, 646-674. [CrossRef]

6. Yap, T.A.; Aerts, J.G.; Popat, S.; Fennell, D.A. Novel insights into mesothelioma biology and implications for therapy. Nat. Rev. Cancer 2017, 17, 475-488. [CrossRef]

7. Mutsaers, S.E. The mesothelial cell. Int. J. Biochem. Cell Biol. 2004, 36, 9-16. [CrossRef]

8. Chu, G.J.; van Zandwijk, N.; Rasko, J.E.J. The Immune Microenvironment in Mesothelioma: Mechanisms of Resistance to Immunotherapy. Front. Oncol. 2019, 9, 1366. [CrossRef] [PubMed]

9. Bueno, R.; Stawiski, E.W.; Goldstein, L.D.; Durinck, S.; De Rienzo, A.; Modrusan, Z.; Gnad, F.; Nguyen, T.T.; Jaiswal, B.S.; Chirieac, L.R.; et al. Comprehensive genomic analysis of malignant pleural mesothelioma identifies recurrent mutations, gene fusions and splicing alterations. Nat. Genet. 2016, 48, 407-416. [CrossRef] [PubMed]

10. Hmeljak, J.; Sanchez-Vega, F.; Hoadley, K.A.; Shih, J.; Stewart, C.; Heiman, D.; Tarpey, P.; Danilova, L.; Drill, E.; Gibb, E.A.; et al. Integrative Molecular Characterization of Malignant Pleural Mesothelioma. Cancer Discov. 2018, 8, 1548-1565. [CrossRef] [PubMed]

11. Dong, H.; Strome, S.E.; Salomao, D.R.; Tamura, H.; Hirano, F.; Flies, D.B.; Roche, P.C.; Lu, J.; Zhu, G.; Tamada, K.; et al. Tumorassociated B7-H1 promotes T-cell apoptosis: A potential mechanism of immune evasion. Nat. Med. 2002, 8, 793-800. [CrossRef]

12. Brcic, L.; Klikovits, T.; Megyesfalvi, Z.; Mosleh, B.; Sinn, K.; Hritcu, R.; Laszlo, V.; Cufer, T.; Rozman, A.; Kern, I.; et al. Prognostic impact of PD-1 and PD-L1 expression in malignant pleural mesothelioma: An international multicenter study. Transl. Lung Cancer Res. 2021, 10, 1594-1607. [CrossRef] [PubMed]

13. Wang, L.; Rubinstein, R.; Lines, J.L.; Wasiuk, A.; Ahonen, C.; Guo, Y.; Lu, L.F.; Gondek, D.; Wang, Y.; Fava, R.A.; et al. VISTA, a novel mouse Ig superfamily ligand that negatively regulates T cell responses. J. Exp. Med. 2011, 208, 577-592. [CrossRef]

14. Vogelzang, N.J.; Rusthoven, J.J.; Symanowski, J.; Denham, C.; Kaukel, E.; Ruffie, P.; Gatzemeier, U.; Boyer, M.; Emri, S.; Manegold, C.; et al. Phase III study of pemetrexed in combination with cisplatin versus cisplatin alone in patients with malignant pleural mesothelioma. J. Clin. Oncol. 2003, 21, 2636-2644. [CrossRef]

15. Van Meerbeeck, J.P.; Gaafar, R.; Manegold, C.; Van Klaveren, R.J.; Van Marck, E.A.; Vincent, M.; Legrand, C.; Bottomley, A.; Debruyne, C.; Giaccone, G.; et al. Randomized phase III study of cisplatin with or without raltitrexed in patients with malignant pleural mesothelioma: An intergroup study of the European Organisation for Research and Treatment of Cancer Lung Cancer Group and the National Cancer Institute of Canada. J. Clin. Oncol. 2005, 23, 6881-6889. [CrossRef] 
16. Zalcman, G.; Mazieres, J.; Margery, J.; Greillier, L.; Audigier-Valette, C.; Moro-Sibilot, D.; Molinier, O.; Corre, R.; Monnet, I.; Gounant, V.; et al. Bevacizumab for newly diagnosed pleural mesothelioma in the Mesothelioma Avastin Cisplatin Pemetrexed Study (MAPS): A randomised, controlled, open-label, phase 3 trial. Lancet 2016, 387, 1405-1414. [CrossRef]

17. Scagliotti, G.V.; Gaafar, R.; Nowak, A.K.; Nakano, T.; van Meerbeeck, J.; Popat, S.; Vogelzang, N.J.; Grosso, F.; Aboelhassan, R.; Jakopovic, M.; et al. Nintedanib in combination with pemetrexed and cisplatin for chemotherapy-naive patients with advanced malignant pleural mesothelioma (LUME-Meso): A double-blind, randomised, placebo-controlled phase 3 trial. Lancet Respir. Med. 2019, 7, 569-580. [CrossRef]

18. Baas, P.; Scherpereel, A.; Nowak, A.K.; Fujimoto, N.; Peters, S.; Tsao, A.S.; Mansfield, A.S.; Popat, S.; Jahan, T.; Antonia, S.; et al. First-line nivolumab plus ipilimumab in unresectable malignant pleural mesothelioma (CheckMate 743): A multicentre, randomised, open-label, phase 3 trial. Lancet 2021, 397, 375-386. [CrossRef]

19. Maio, M.; Scherpereel, A.; Calabro, L.; Aerts, J.; Perez, S.C.; Bearz, A.; Nackaerts, K.; Fennell, D.A.; Kowalski, D.; Tsao, A.S.; et al. Tremelimumab as second-line or third-line treatment in relapsed malignant mesothelioma (DETERMINE): A multicentre, international, randomised, double-blind, placebo-controlled phase 2b trial. Lancet Oncol. 2017, 18, 1261-1273. [CrossRef]

20. Popat, S.; Curioni-Fontecedro, A.; Dafni, U.; Shah, R.; O'Brien, M.; Pope, A.; Fisher, P.; Spicer, J.; Roy, A.; Gilligan, D.; et al. A multicentre randomised phase III trial comparing pembrolizumab versus single-agent chemotherapy for advanced pre-treated malignant pleural mesothelioma: The European Thoracic Oncology Platform (ETOP 9-15) PROMISE-meso trial. Ann. Oncol. 2020, 31, 1734-1745. [CrossRef] [PubMed]

21. Fennell, D.; Ottensmeier, C.; Califano, R.; Hanna, G.; Ewings, S.; Hill, K.; Wilding, S.; Danson, S.; Nye, M.; Steele, N.; et al. PS01.11 Nivolumab Versus Placebo in Relapsed Malignant Mesothelioma: The CONFIRM Phase 3 Trial. J. Thorac. Oncol. 2021, 16 (Suppl. 62). [CrossRef]

22. Antonia, S.J.; Villegas, A.; Daniel, D.; Vicente, D.; Murakami, S.; Hui, R.; Yokoi, T.; Chiappori, A.; Lee, K.H.; de Wit, M.; et al. Durvalumab after Chemoradiotherapy in Stage III Non-Small-Cell Lung Cancer. N. Engl. J. Med. 2017, 377, 1919-1929. [CrossRef]

23. Gandhi, L.; Rodriguez-Abreu, D.; Gadgeel, S.; Esteban, E.; Felip, E.; De Angelis, F.; Domine, M.; Clingan, P.; Hochmair, M.J.; Powell, S.F.; et al. Pembrolizumab plus Chemotherapy in Metastatic Non-Small-Cell Lung Cancer. N. Engl. J. Med. 2018, 378, 2078-2092. [CrossRef] [PubMed]

24. Horn, L.; Mansfield, A.S.; Szczesna, A.; Havel, L.; Krzakowski, M.; Hochmair, M.J.; Huemer, F.; Losonczy, G.; Johnson, M.L.; Nishio, M.; et al. First-Line Atezolizumab plus Chemotherapy in Extensive-Stage Small-Cell Lung Cancer. N. Engl. J. Med. 2018, 379, 2220-2229. [CrossRef]

25. Reck, M.; Rodriguez-Abreu, D.; Robinson, A.G.; Hui, R.; Csoszi, T.; Fulop, A.; Gottfried, M.; Peled, N.; Tafreshi, A.; Cuffe, S.; et al. Pembrolizumab versus Chemotherapy for PD-L1-Positive Non-Small-Cell Lung Cancer. N. Engl. J. Med. 2016, 375, 1823-1833. [CrossRef]

26. Calabro, L.; Morra, A.; Fonsatti, E.; Cutaia, O.; Amato, G.; Giannarelli, D.; Di Giacomo, A.M.; Danielli, R.; Altomonte, M.; Mutti, L.; et al. Tremelimumab for patients with chemotherapy-resistant advanced malignant mesothelioma: An open-label, single-arm, phase 2 trial. Lancet Oncol. 2013, 14, 1104-1111. [CrossRef]

27. Alley, E.W.; Lopez, J.; Santoro, A.; Morosky, A.; Saraf, S.; Piperdi, B.; van Brummelen, E. Clinical safety and activity of pembrolizumab in patients with malignant pleural mesothelioma (KEYNOTE-028): Preliminary results from a non-randomised, open-label, phase $1 \mathrm{~b}$ trial. Lancet Oncol. 2017, 18, 623-630. [CrossRef]

28. De Gooijer, C.J.; Borm, F.J.; Scherpereel, A.; Baas, P. Immunotherapy in Malignant Pleural Mesothelioma. Front. Oncol. 2020, 10, 187. [CrossRef]

29. Calabro, L.; Morra, A.; Giannarelli, D.; Amato, G.; D’Incecco, A.; Covre, A.; Lewis, A.; Rebelatto, M.C.; Danielli, R.; Altomonte, M.; et al. Tremelimumab combined with durvalumab in patients with mesothelioma (NIBIT-MESO-1): An open-label, nonrandomised, phase 2 study. Lancet Respir. Med. 2018, 6, 451-460. [CrossRef]

30. Scherpereel, A.; Mazieres, J.; Greillier, L.; Lantuejoul, S.; Do, P.; Bylicki, O.; Monnet, I.; Corre, R.; Audigier-Valette, C.; LocatelliSanchez, M.; et al. Nivolumab or nivolumab plus ipilimumab in patients with relapsed malignant pleural mesothelioma (IFCT-1501 MAPS2): A multicentre, open-label, randomised, non-comparative, phase 2 trial. Lancet Oncol. 2019, 20, 239-253. [CrossRef]

31. Mankor, J.M.; Disselhorst, M.J.; Poncin, M.; Baas, P.; Aerts, J.; Vroman, H. Efficacy of nivolumab and ipilimumab in patients with malignant pleural mesothelioma is related to a subtype of effector memory cytotoxic $\mathrm{T}$ cells: Translational evidence from two clinical trials. EBioMedicine 2020, 62, 103040. [CrossRef]

32. FDA Approves Drug Combination for Treating Mesothelioma. Available online: https://www.fda.gov/news-events/pressannouncements/fda-approves-drug-combination-treating-mesothelioma (accessed on 1 October 2021).

33. European Medicines Agency. Available online: https://www.ema.europa.eu/en/medicines/human/EPAR/opdivo (accessed on 1 October 2021).

34. Forde, P.M.; Sun, Z.; Anagnostou, V.; Kindler, H.L.; Purcell, W.T.; Goulart, B.H.L.; Dudek, A.Z.; Borghaei, H.; Brahmer, J.R.; Ramalingam, S.S. PrE0505: Phase II multicenter study of anti-PD-L1, durvalumab, in combination with cisplatin and pemetrexed for the first-line treatment of unresectable malignant pleural mesothelioma (MPM)—A PrECOG LLC study. J. Clin. Oncol. 2020, 38, 9003. [CrossRef]

35. Gardner, A.; de Mingo Pulido, A.; Ruffell, B. Dendritic Cells and Their Role in Immunotherapy. Front. Immunol. 2020, 11, 924. [CrossRef] [PubMed] 
36. Marcq, E.; Van Audenaerde, J.R.M.; De Waele, J.; Merlin, C.; Pauwels, P.; van Meerbeeck, J.P.; Fisher, S.A.; Smits, E.L.J. The Search for an Interesting Partner to Combine with PD-L1 Blockade in Mesothelioma: Focus on TIM-3 and LAG-3. Cancers 2021, 13, 282. [CrossRef] [PubMed]

37. Jiang, Q.; Ghafoor, A.; Mian, I.; Rathkey, D.; Thomas, A.; Alewine, C.; Sengupta, M.; Ahlman, M.A.; Zhang, J.; Morrow, B.; et al. Enhanced efficacy of mesothelin-targeted immunotoxin LMB-100 and anti-PD-1 antibody in patients with mesothelioma and mouse tumor models. Sci. Transl. Med. 2020, 12. [CrossRef]

38. Hegmans, J.P.; Veltman, J.D.; Lambers, M.E.; de Vries, I.J.; Figdor, C.G.; Hendriks, R.W.; Hoogsteden, H.C.; Lambrecht, B.N.; Aerts, J.G. Consolidative dendritic cell-based immunotherapy elicits cytotoxicity against malignant mesothelioma. Am. J. Respir. Crit. Care Med. 2010, 181, 1383-1390. [CrossRef]

39. Dumoulin, D.W.; Cornelissen, R.; Bezemer, K.; Baart, S.J.; Aerts, J. Long-Term Follow-Up of Mesothelioma Patients Treated with Dendritic Cell Therapy in Three Phase I/II Trials. Vaccines 2021, 9, 525. [CrossRef] [PubMed]

40. Adusumilli, P.S.; Zauderer, M.G.; Riviere, I.; Solomon, S.B.; Rusch, V.W.; O'Cearbhaill, R.E.; Zhu, A.; Cheema, W.; Chintala, N.K.; Halton, E.; et al. A Phase I Trial of Regional Mesothelin-Targeted CAR T-cell Therapy in Patients with Malignant Pleural Disease, in Combination with the Anti-PD-1 Agent Pembrolizumab. Cancer Discov. 2021, 11, 2748-2763. [CrossRef]

41. Klampatsa, A.; Albelda, S.M. Current Advances in CAR T Cell Therapy for Malignant Mesothelioma. J. Cell Immunol. 2020, 2, 192-200. [CrossRef]

42. Sterman, D.H.; Haas, A.; Moon, E.; Recio, A.; Schwed, D.; Vachani, A.; Katz, S.I.; Gillespie, C.T.; Cheng, G.; Sun, J.; et al. A trial of intrapleural adenoviral-mediated Interferon-alpha2b gene transfer for malignant pleural mesothelioma. Am. J. Respir. Crit. Care Med. 2011, 184, 1395-1399. [CrossRef] 